\title{
DYNAMIC PROPERTIES OF PURKINJE CELLS HAVING DIFFERENT ELECTROPHYSIOLOGICAL PARAMETERS: A MODEL STUDY
}

\author{
Received December 2, 2013
}

\begin{abstract}
Simple spikes and complex spikes are two distinguishing features in neurons of the cerebellar cortex; the motor learning and memory processes are dependent on these firing patterns. In our research, the detailed firing behaviors of Purkinje cells were investigated using a computer compartmental neuronal model. By means of application of numerical stimuli, the abundant dynamical properties involved in the multifarious firing patterns, such as the Max-Min potentials of each spike and period-adding/period-doubling bifurcations, appeared. Neuronal interspike interval (ISI) diagrams, frequency diagrams, and current-voltage diagrams for different ions were plotted. Finally, Poincare mapping was used as a theoretical method to strongly distinguish timing of the above firing patterns. Our simulation results indicated that firing of Purkinje cells changes dynamically depending on different electrophysiological parameters of these neurons, and the respective properties may play significant roles in the formation of the mentioned characteristics of dynamical firings in the coding strategy for information processing and learning.
\end{abstract}

Keywords: Purkinje cell, computer compartmental model, Max-Min potential, interspike intervals (ISIs), current-voltage diagram, frequency, Poincare mapping.

\section{INTRODUCTION}

Purkinje cells of the cerebellar cortex are some of the largest neurons in the brains of mammals (including humans) [1]. These cells have an intricately elaborated dendritic arborization characterized by an enormous number of dendritic spines. Purkinje cells receive two main excitatory inputs, from climbing fibers and parallel fibers, and two inhibitory inputs, from basket cells and stellate cells [2, 3]. The literature on the Purkinje cell models and simulation of their spiking behaviors is very rich. In particular, it was found in detailed models of these cells that the $\mathrm{Ca}^{2+}$ dynamics are effectively controlled by $\mathrm{Ca}^{2+}$-activated $\mathrm{K}^{+}$channels, and that a compensating mechanism largely eliminates the effect by removing diffusion in a model on the $\mathrm{Ca}^{2+}$ dynamics over multiple time scales [4]. Transition from bursting to high-frequency single spikes in a reduced mathematical model of a

\footnotetext{
South China University of Technology, Department of Mathematics, Guangzhou, China.

${ }^{2}$ Beijing University of Technology, Biomedical Engineering Center, Beijing, China.

Correspondence should be addressed to S. Q. Liu or Y. J. Zeng

(e-mail: yjzeng@bjut.edu.cn)
}

cerebellar Purkinje cell was studied; some results on the influence of tetrodotoxin (TTX) and cAMP on the activity of Purkinje cells were also described $[5,6]$. Ion currents underlying generation of spontaneous action potentials (APs) were examined by Raman [7].

There are two distinct forms of electrophysiological activity of Purkinje cells. Simple spikes occur at rates of 17 to $50 \mathrm{sec}^{-1}$ [7], while complex spikes are generated much more rarely, with a $1-3 \mathrm{sec}^{-1}$ frequency. The latter spikes are characterized by an initial prolonged high-amplitude component followed by a high-frequency bursting of smaller-amplitude APs. The two electrophysiological activities are closely related to the functioning of sodium and calcium channels. It was recently shown that activation of climbing fibers terminating on the Purkinje cell can shift its activity from a quiet state to a spontaneously active state and, vice versa, can serve as a type of the toggle switch [7].

However, all the papers mentioned above were based on examination of a complete Purkinje cell, and the impact of definite separate electrophysiological parameters has not been studied in these cases. Based on the anatomical data, we constructed a computer single somatic compartmental model allowing us to separately study the influences of external stimuli, ion conductances, and temperature on firing patterns of the 
Purkinje cell. Then we analyzed the Max-Min potential, neuronal ISIs observed under different situations, changes in the spiking frequency, and current-voltage diagrams for different ions. Finally, we exploited the Poincare mapping to further distinguish different firing patterns generated by the model of the Purkinje cell used.

\section{METHODS}

To deeply examine the complex spike phenomenon, we in this study employed some earlier papers to describe the necessary ion channels and equations [810]. The somatic compartment includes eight channel types, namely two $\mathrm{Na}^{+}$channels, three $\mathrm{Ca}^{2+}$ channels, two $\mathrm{K}^{+}$channels, and leak channels; the details are shown in Fig. 1.

According to the classic Hodgkin-Huxley model [11], the description of the membrane potential in this neuron is performed using the following equation:

$$
\frac{\mathrm{dN}}{\mathrm{dt}}=\frac{1}{C_{M}}\left(I_{\text {et }}-I_{\mathrm{NaF}}-I_{\mathrm{NaP}}-I_{\mathrm{CaP} 2}-I_{\mathrm{CaT}}-I_{\mathrm{CaE}}-I_{\mathrm{KD}}-I_{\mathrm{Kh}}-I_{\mathrm{L}}\right)
$$

where $\mathrm{V}$ represents the membrane potential, the membrane capacitance $\mathrm{C}_{\mathrm{M}}$ is $0.8 \mu \mathrm{F} / \mathrm{cm}^{2}, I_{\text {ext }}$ and $\mathrm{I}_{\mathrm{L}}$ represent the external current and the leak current, and other components separately represent all kinds of ion currents. The entire ion conductance can be depicted by classic Hodgkin-Huxley formalism:

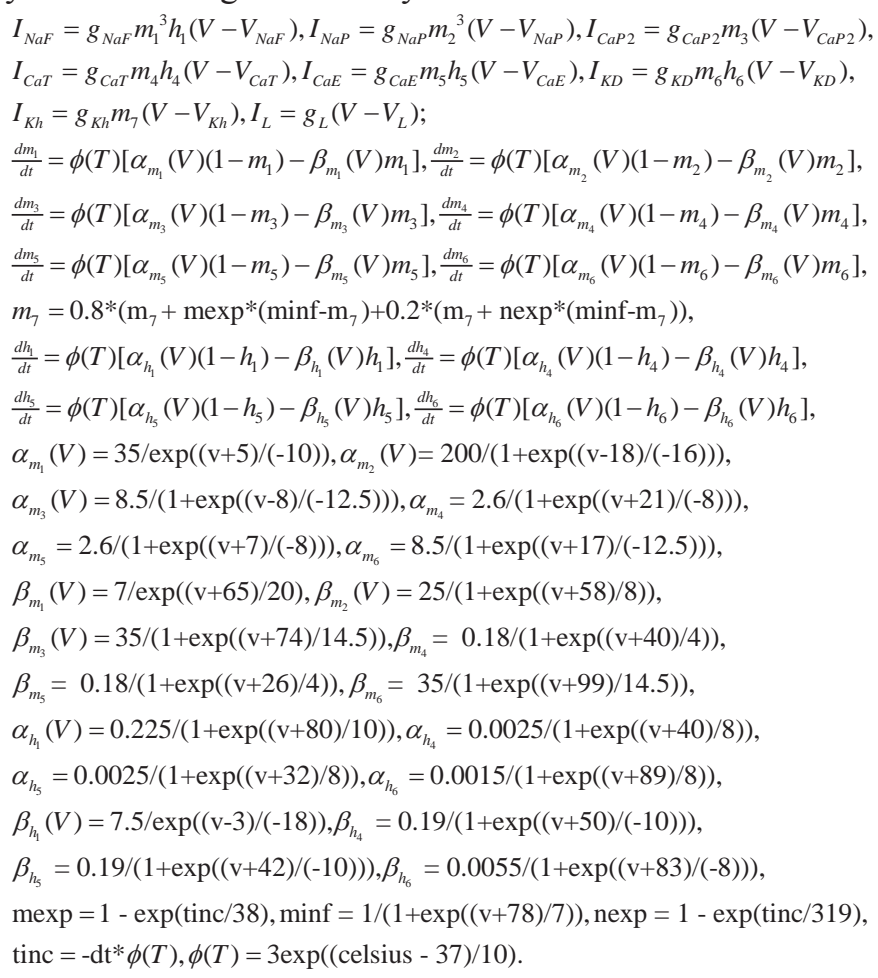
tinc $=-\mathrm{dt}^{*} \phi(\mathrm{T}), \phi(\mathrm{T})=3 \exp (($ celsius -37$) / 10)$.

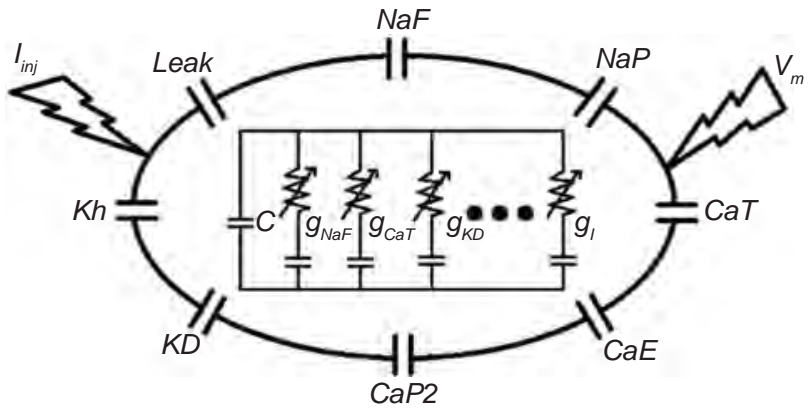

F i g. 1. Scheme of the model of the Purkinje cell somatic compartment; inside, the electrical diagram of this compartment is shown.

Р и с. 1. Схема моделі соматичного компартмента клітини Пуркін'є (всередині наведено електричну діаграму цього компартмента).

where $m_{\mathrm{n} 1}$ and $\mathrm{h}_{\mathrm{n} 2}(\mathrm{n} 1=1 \sim 7, \mathrm{n} 2=1,4,5,6)$ are gating variables representing the activation and inactivation of different ion $\alpha_{\mathrm{m}_{\mathrm{n} 3}}, \beta_{\mathrm{m}_{\mathrm{n} 3}}, \alpha_{\mathrm{m}_{\mathrm{n} 4}}$, and $\beta_{\mathrm{m}_{\mathrm{n} 4}}$ channels, $(\mathrm{n} 3=1 \sim 6, \mathrm{n} 4=1,4,5,6)$ are some necessary parameters of the $\mathrm{V}$. The equilibrium potentials for each ion channel and leak potential are $\mathrm{V}_{\mathrm{NaP}} V_{\mathrm{NaP}}, V_{\mathrm{CaP} 2}$, $\mathrm{V}_{C a E}, V_{C a T}, V_{K D}, V_{K h}$, and $V_{\text {Leak }}$. Varied ion conductances are $g_{\mathrm{NaP}}, g_{\mathrm{NaP}}, g_{\mathrm{CaP} 2}, g_{\mathrm{CaE}}, g_{\mathrm{CaT}}, g_{K D}, g_{K h}$, and $g_{\text {Leak }} ; \Phi(T)$ is the temperature factor. Some parameters shown above are the following: $\mathrm{V}_{\mathrm{NaF}}=45 \mathrm{mV}, \mathrm{V}_{\mathrm{NaP}}=45 \mathrm{mV}$, $\mathrm{V}_{C a P 2}=135 \mathrm{mV}, \mathrm{V}_{C a T}=135 \mathrm{mV}, \mathrm{V}_{C a E}=135 \mathrm{mV}$, $\mathrm{V}_{K D}=-85 \mathrm{mV}, \mathrm{V}_{K h}=-30 \mathrm{mV}$, and $V_{\text {leak }}=-30 \mathrm{mV}$, $\mathrm{g}_{\mathrm{NaF}}=7.5, \mathrm{~g}_{\mathrm{Na \textrm {P }}}=0.01, \mathrm{~g}_{\mathrm{CaP2}}=0.0045, \mathrm{~g}_{\mathrm{CaT}}=0.0005$, $\mathrm{g}_{C a T}=0.0005, \mathrm{~g}_{K D}=0.0045, \mathrm{~g}_{K h}=-30$, and $\mathrm{g}_{\text {leak }}=0.0003 \mathrm{msec} / \mathrm{cm}^{2}$.

All simulations were performed using NEURON software, and we used MATLAB software to process the data.

\section{RESULTS}

Impact of Different External Stimuli. As was described in the earlier paper $[5,12]$, when the soma is separately stimulated with direct current, alternating current, and square-wave current, the firing patterns generated by the model are different (Fig. 2A). The differences appear in the potential amplitude and the spike frequency.

Furthermore, when we stimulated the soma with $0.29 \mathrm{nA}$ direct current, the following was found (Fig. 2B). When the firing patterns in the soma were modified, the $\mathrm{Ca}^{2+}$ concentration changed, and all the ion currents changed synchronously. The difference 
A
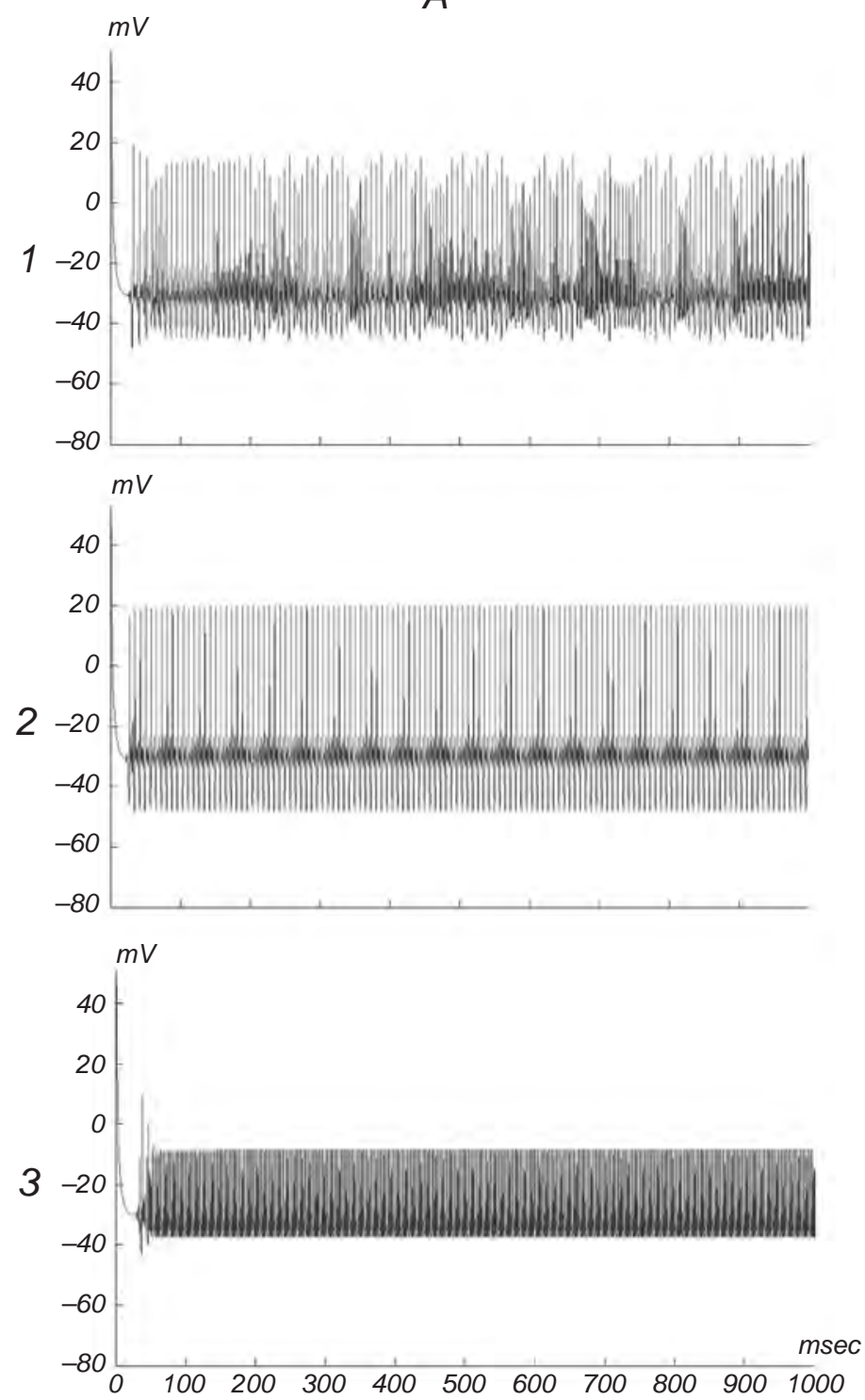

$B$
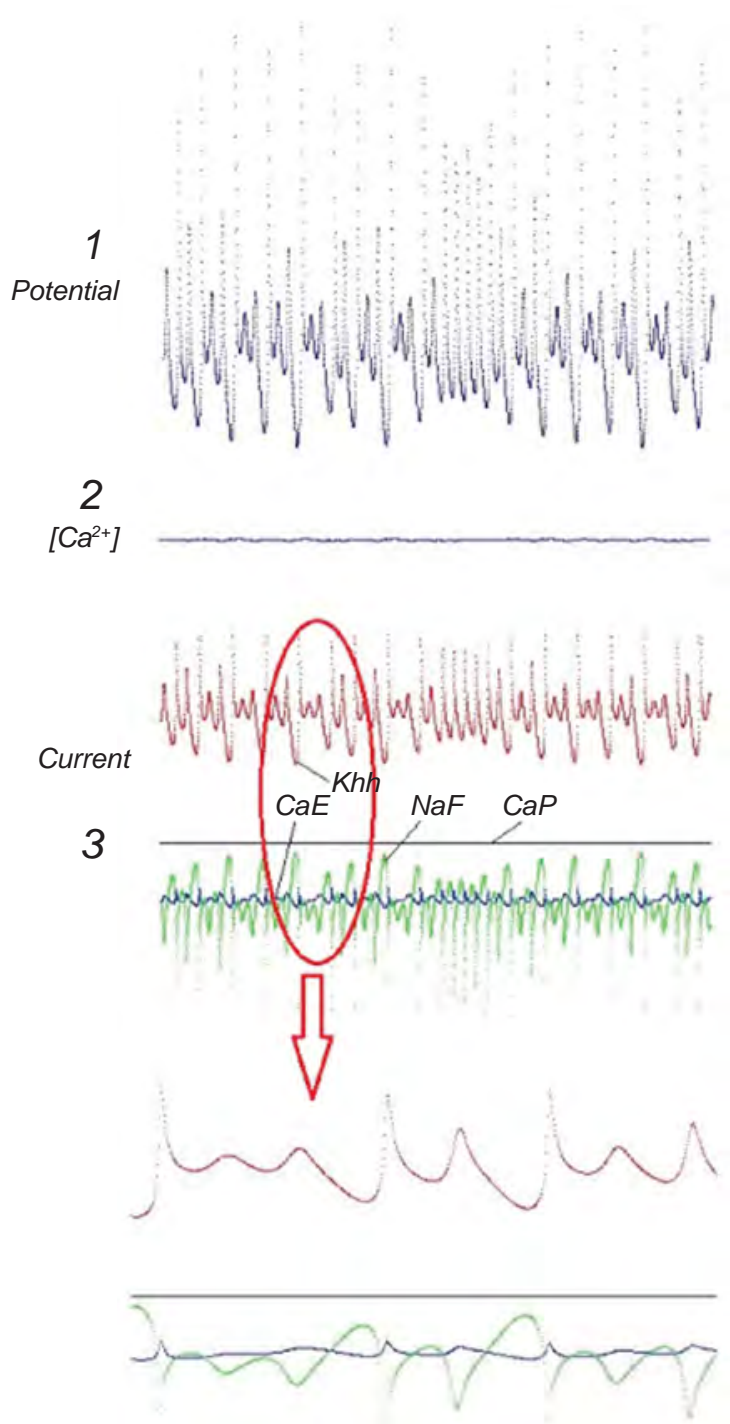

F i g. 2. Effects of changes in the stimulus intensity. A) Firing patterns in the soma at application of different stimuli: 0.29 nA (1), $0.29 \cdot(\mathrm{t} \% 100>85) \mathrm{nA}(2)$, and $0.29+0.29 \sin (0.02 \mathrm{t}) \mathrm{nA}(3)$, duration $1000 \mathrm{msec}$. B) Changes in the membrane potential $(1)$, Ca ${ }^{2+}$ concentration (2), and all stimulated ions currents (3).

Р и с. 2. Впливи змін інтенсивності стимуляції.

is that changes of the $\mathrm{K}^{+}$current were positive, while those of $\mathrm{Ca}^{2+}$ and $\mathrm{Na}^{+}$currents were negative. We should notice that the $\mathrm{CaP}$ current always remains at a $0 \mathrm{nA}$ level. The simulation results are similar to the published experimental ones [5]. The firing pattern changes significantly when the stimulus intensity increases. When the stimulus was around $3 \mathrm{nA}$, a huge transition appeared. After this, some oscillations were observed, and the amplitude of the latter decreased.

The ISI diagram (Fig. 4A) shows that the global change includes a slow fall and a fast increase. The
Max-Min potential diagram, however, demonstrates the clear period-adding and period-doubling bifurcation phenomena are manifested with increase in the stimulus intensity. When the stimulus was varied between 3.0 and $3.3 \mathrm{nA}$, the clear perioddoubling bifurcation phenomenon could be observed. When the above parameter varied between 2.6 and $3.0 \mathrm{nA}$, the firing sequences in the soma showed the period-doubling bifurcation and inverse perioddoubling bifurcation. The period-adding bifurcation phenomenon was also initiated when the stimulus 
$A$

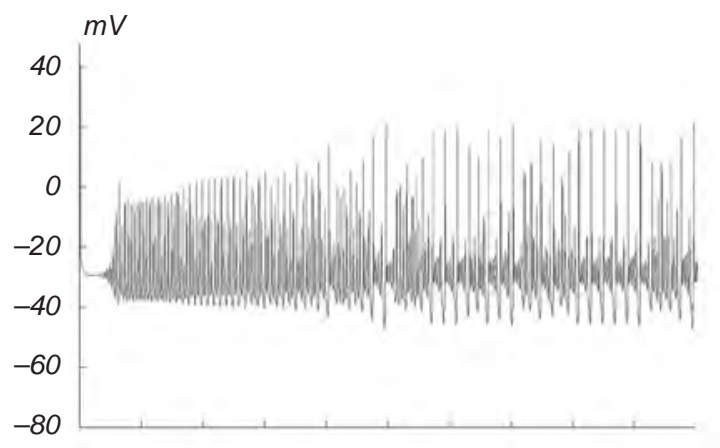

C

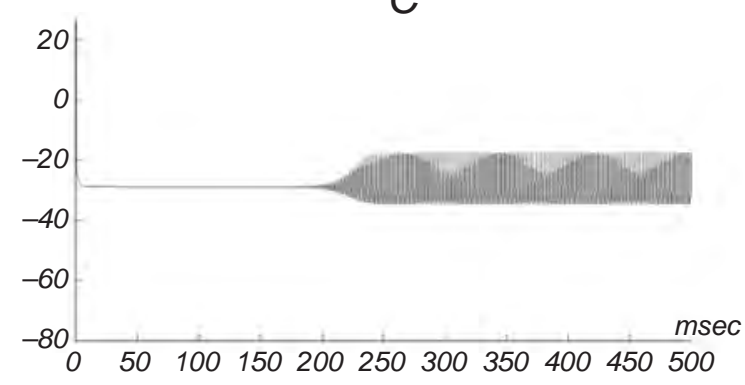

$B$

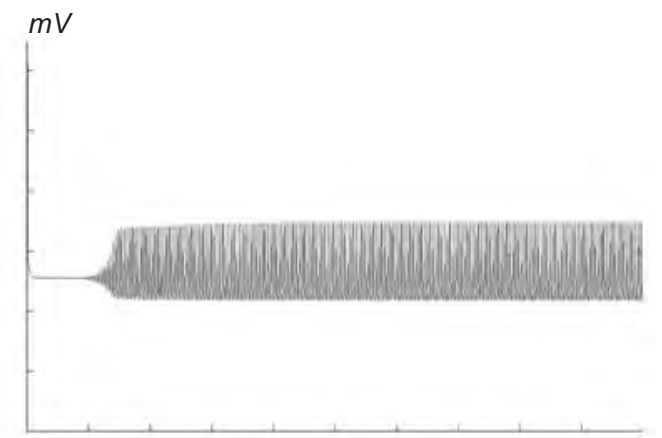

$D$
F i g. 3. Oscillations in the soma. A-D) The stimuli are $2.99,3.16$, 3.24 , and $3.27 \mathrm{nA}$, respectively; duration $500 \mathrm{msec}$.

Р и с. 3. Осциляції в сомі. varied from 2.2 to $2.6 \mathrm{nA}$. In this case, the firing sequence changed from period-2 spiking doubling to period-4 spiking doubling. Moreover, when the stimulus intensity increased, the frequency of spikes increased from 0 to more than $50 \mathrm{sec}^{-1}$; then, after a slow increase, it dropped to 0 .

In Fig. 4B, the same approach was used to analyze behavior of a granule cell (compared to A). The ISI diagram shows the distinct period-adding and perioddoubling bifurcation phenomena both from global and local aspects, but the Max-Min potential diagram is very complex.

The aforementioned analysis shows that the external stimuli exert a powerful influence on somatic spike activities. The observed rich diverse spike patterns and some dynamic properties help us to further understand the generation and conduction of neuronal AP sequences in the cell under study.

Impact of Different CaT Conductances. Calcium ions have been proved to play a very important role in the functioning of cerebellar networks [4, 12, 13]. In particular, some analysis of the work of $\mathrm{P} / \mathrm{Q}-$ Type calcium channels related to calcium-activated potassium channels was carried out [14-16]. The main ion channels working in our neuronal compartmental model were calcium, sodium, and potassium ones. For different ions, the integral conductances reflect the densities of different ion channels, and variations of this conductance show the extent of opening of ion channels and the processes of ion accumulation. These factors affect the generation of APs; so, the detailed research of the $\mathrm{CaT}$ conductance is expedient.

As we can see in Fig. 5A, 1, the ISI diagram demonstrated an unclear period-doubling bifurcation; at the same time, the Max-Min diagram $(B, 1)$ shows an exquisite period-adding phenomenon where the CaT conductance changes from 0.46 to $0.67 \mathrm{msec} / \mathrm{cm}^{2}$. The period-doubling and inverse period-doubling bifurcation phenomena appear with increase in the CaT conductance from 0.22 to $0.46 \mathrm{msec} / \mathrm{cm}^{2}$; and this is followed by a period-adding phenomenon when the CaT conductance varied from 0 to $0.22 \mathrm{msec} / \mathrm{cm}^{2}$. During this process, the firing sequence in the soma changes from period-2 spiking doubling to period-4 spiking doubling (sometimes, even to period-8 spiking doubling). Besides this, we analyzed the frequency of spiking related to different $\mathrm{CaT}$ conductances. The general tendency was almost the same as that when the stimulus intensity increased, but the conspicuous difference is that the spike frequency is not zero when the CaT conductance is $0 \mathrm{msec} / \mathrm{cm}^{2}$.

Considering the results of the above analysis, it can be concluded that the influence of the CaT conductance on neuronal activities is extraordinarily important. Abundant spike patterns were observed with variations of the CaT conductance. These facts confirm that the state of the $\mathrm{Ca}^{2+}$ system is extremely important the Purkinje cells. 
A
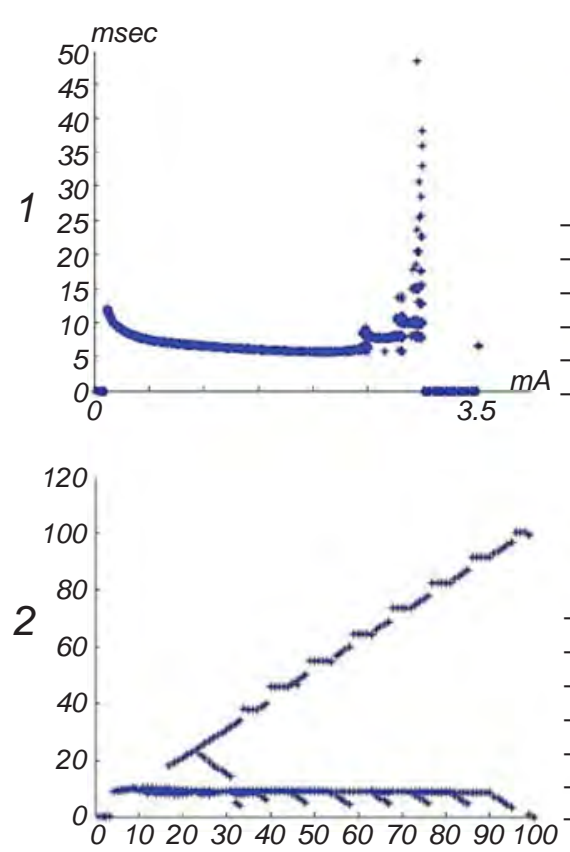

$B$

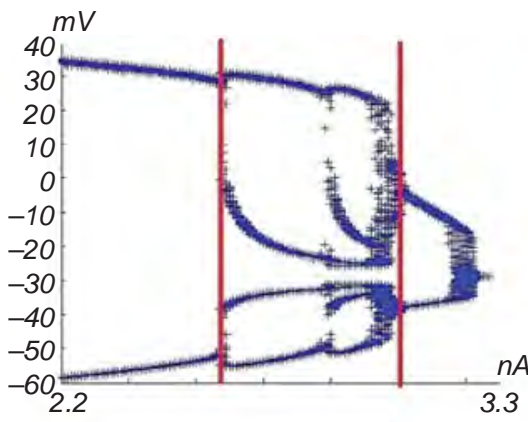

C

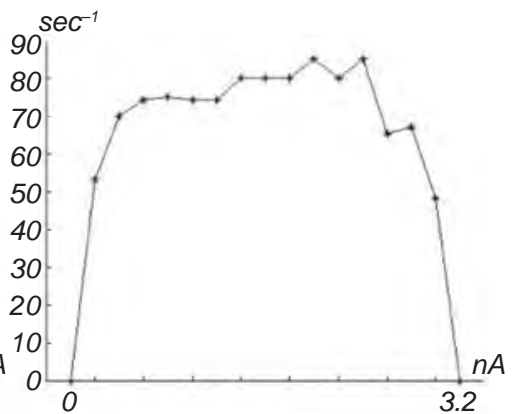

F i g. 4. ISI bifurcation diagrams, bifurcation diagrams of Max-Min potentials, and frequency diagrams (A-C, respectively); 1 and 2 ) effects of changes in the stimulation intensity applied to the Purkinje cell soma (1) and to the granule cell (2).

Р и с. 4. Діаграми біфуркацій міжімпульсних інтервалів, біфуркацій максимальних/мінімальних потенціалів та змін частоти (А-С відповідно) в умовах змін інтенсивності стимуляції соми клітини Пуркін'є (1) та гранулярної клітини (2).

Impact of Different NaF Conductances. It was shown that the parameters of electrophysiological activity of Purkinje cells are both sodium- and calcium-dependent [6]. Based on the model approach, Scutter and Bower [12] got some differential equations and relevant parameters. Later on, Miyasho et al. [13] subjected to further studies impacts of the some ion conductances for $\mathrm{Ca}^{2+}$ and $\mathrm{K}^{+}$on the generation of APs by comparing different firing patterns observed in the soma and dendrites. Here, we mainly analyze the impact of the $\mathrm{NaF}$ conductance.

In Fig. 5B, the ISI graph shows that there is a similar period-2 doubling bifurcation phenomenon. According to the Max-Min diagram, the firing sequence in the soma shows a noticeable period-adding phenomenon with increase in the $\mathrm{NaF}$ conductance from 5 to $31 \mathrm{msec} / \mathrm{cm}^{2}$. When the NaF conductance changes from 26.7 to $27.1 \mathrm{msec} / \mathrm{cm}^{2}$, both the maximum and minimum potentials change suddenly. This event is not a gradually developing process; the potentials change at once, and we still could not find the meticulous process in the detailed analysis. The frequency change is the same as that when the stimulus intensity increased. This parameter rises from 0 to around $70 \mathrm{sec}^{-1}$ and then decreases gradually to zero when the
$\mathrm{NaF}$ conductance reaches $31 \mathrm{msec} / \mathrm{cm}^{2}$.

The $\mathrm{NaF}$ conductance is very important for the formation of firing patterns and transmission processes of neuronal potential sequences. The approaches used in the analysis (bifurcation diagrams of the Max-Min potential and ISI diagrams) give us some inspirations to deeply acquire the conduction of neuronal potential.

Impact of Different Temperature. Temperature is a very important factor influencing firing patterns generated by all kinds of neurons; however, information on the temperature effects remains relatively limited [17]. In our model, we estimated the temperature impact on the Hodgkin-Huxley model of a Purkinje cell.

In Fig. 5C, graph A shows the ISI diagram, while graph B is the Max-Min diagram when the temperature increases from 22 to $63^{\circ} \mathrm{C}$. The firing sequences in the soma show in this case obvious period-adding and period-doubling phenomena. The firing is transformed into the chaotic one, in particular, when the temperature varied from 22 to around $40^{\circ} \mathrm{C}$. Within this interval, the firing sequence in the soma changed from period-2 spiking doubling to period-4 spiking and to period-16 spiking in a nonperiodic manner. In graph $\mathrm{C}$, the frequency of spikes gradually increased when 

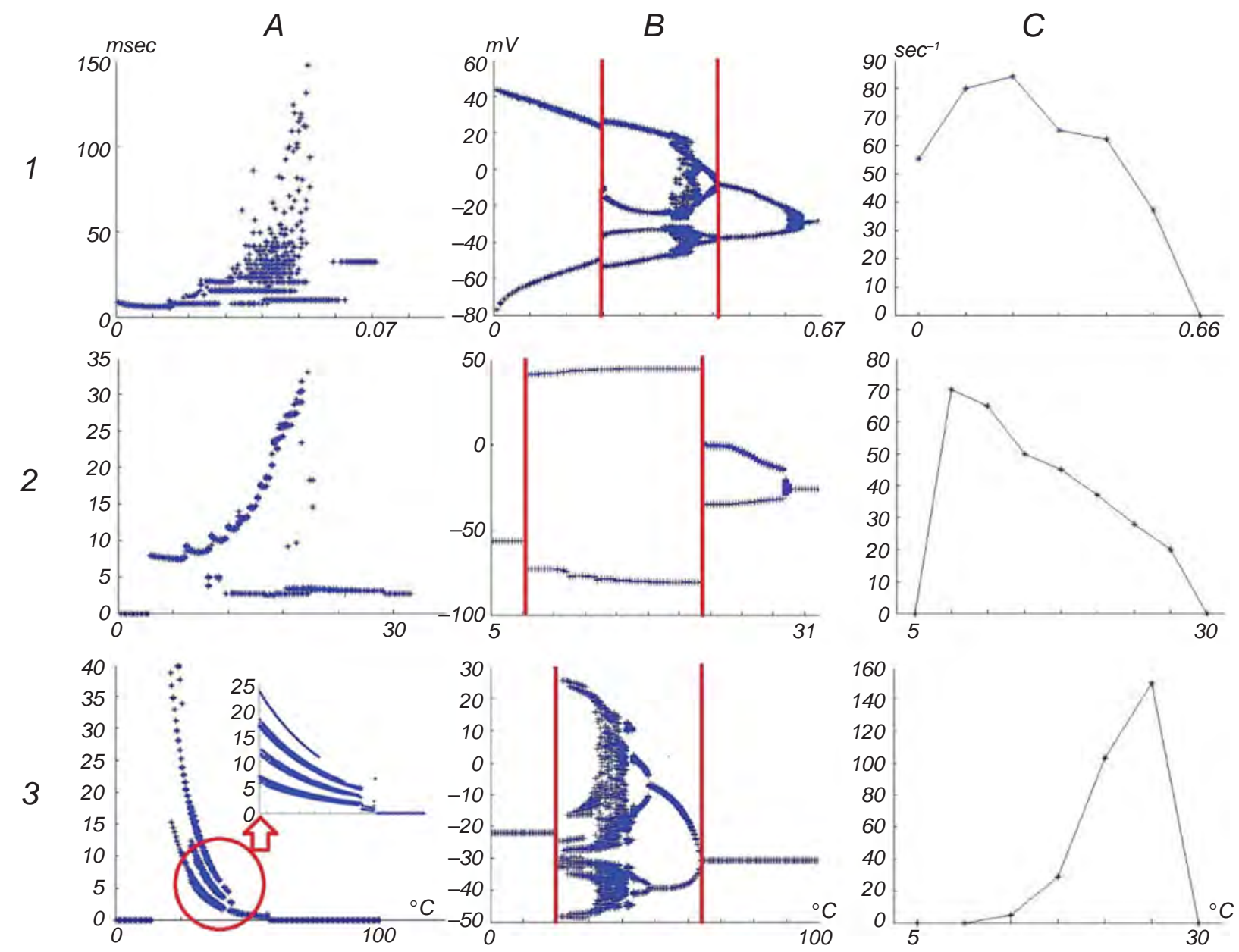

Fig. 5. ISI bifurcation diagrams, bifurcation diagrams of Max-Min potentials, and frequency diagrams (A-C, respectively); from 1 to 3 , changes in the CaT conductance (1), NaF conductance (2), and temperature (3).

Р и с. 5. Діаграми біфуркацій міжімпульсних інтервалів, біфуркацій максимальних/мінімальних потенціалів та змін частоти (А-C відповідно) в умовах змін СaT- i NaF-провідності, а також температури (1-3 відповідно).

the temperature changed from 0 to $50^{\circ} \mathrm{C}$ and rapidly decreased to zero when the temperature changed from 50 to $60^{\circ} \mathrm{C}$. Thus, there was no spiking under the latter extreme conditions, where the model leaves the adequate temperature range.

In any case, the temperature is an especially pivotal factor with respect to the Purkinje cell (the prototype of our model), and, with no doubts, it would also crucially influence spike activity of other neuronal types. Estimation of different firing sequences, the bifurcation phenomenon of Max-Min potential, and other results of simulation, would help us to study the functioning of different neuronal species in subsequent research.

Analysis of Current-Voltage Diagrams for Different Ions. As is generally known according to the basic Ohm's law formula, the electric resistance is equal to a voltage/current ratio. We can introduce this formula to gain the "electric resistance" relationship in our model. According to the former analyses, potassium channel could be considered an analog of the inductance circuit in some their characteristics; so, the electric resistance can transformed into the classical currentvoltage mode [16]. We used this approach to plot the current-voltage graphs. When we estimated the impact of temperature (see above), the bifurcation diagrams changed from chaotic to periodical modes, and we used the temperature factor in the analysis of changes in the electric resistance.

As can be seen in Fig. 6, the current-voltage diagrams were significantly modified with the temperature changes. As is obvious from the top diagram, the firing pattern of the soma is disordered, and the current-voltage diagrams for three ions are 


\section{A}
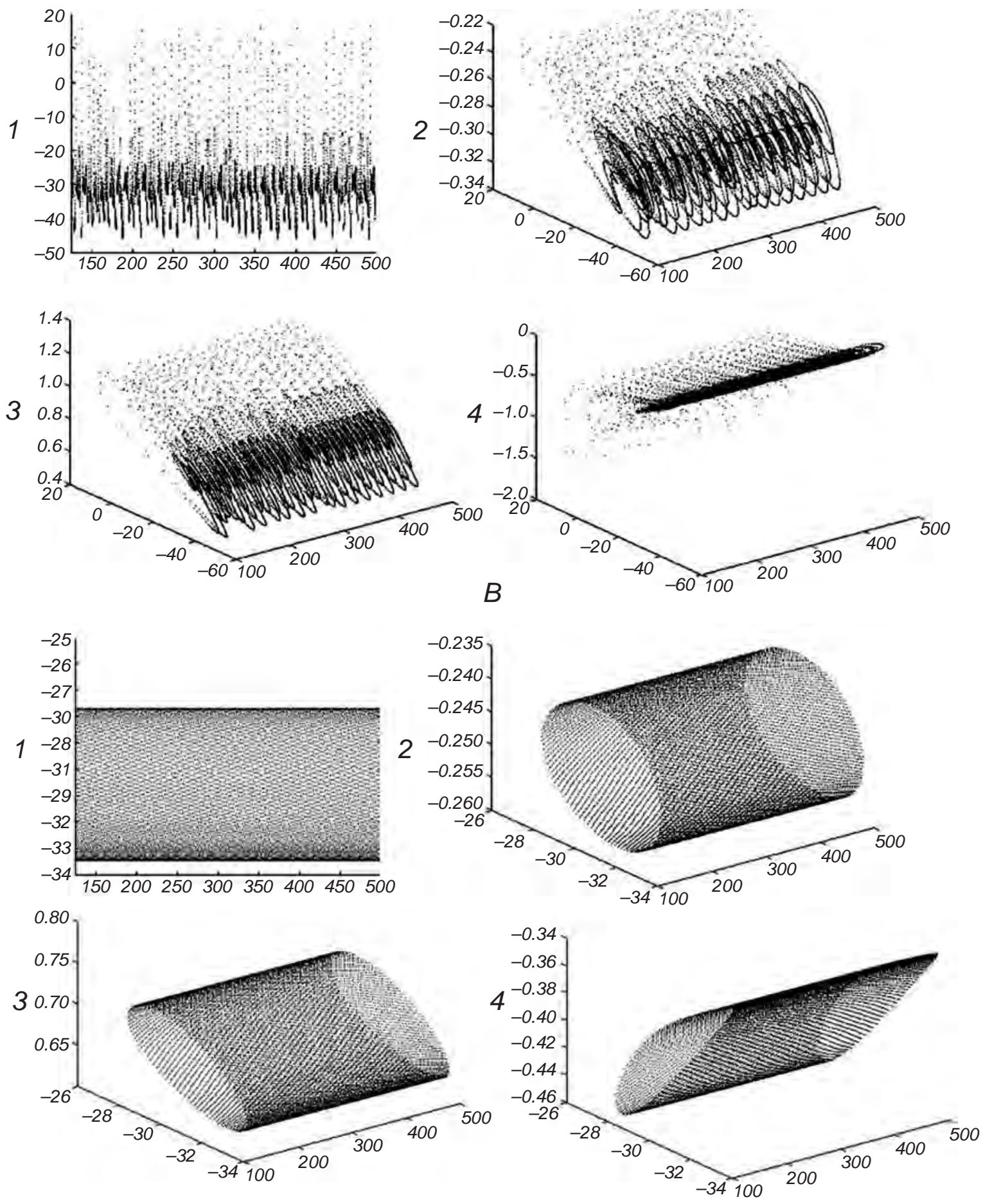

F i g. 6. Current-voltage diagrams for different ions at different temperatures. A and $\mathrm{B}$, at 36 and $63{ }^{\circ} \mathrm{C}$; 1 ) for $\mathrm{Ca}^{2+}$; 2) for $\mathrm{K}^{+}$; 3 ) for $\mathrm{Na}^{+}$.

Р и с. 6. Діаграми струм-потенціал для різних іонів при змінах температури.

not regular. However, all the bottom diagrams were transformed into irregular ellipses, and a periodical mode appears. It seems that some bioelectrical characteristics could be obtained easily, and the electric resistances for different ion channels might be associated with changes in the potential of the neuron 
A
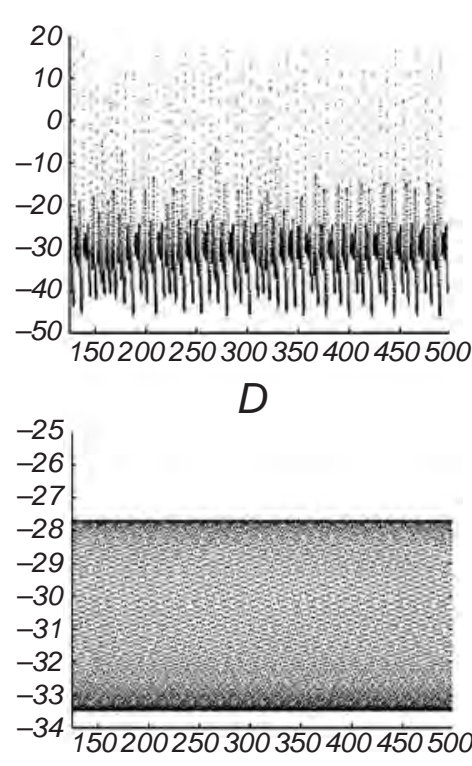

$B$

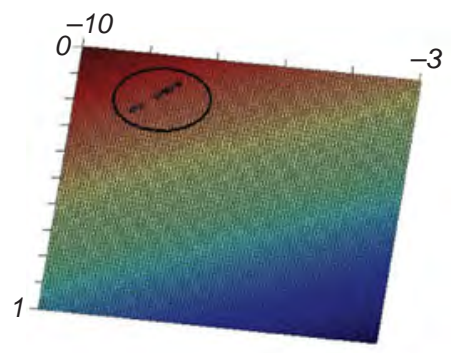

$E$

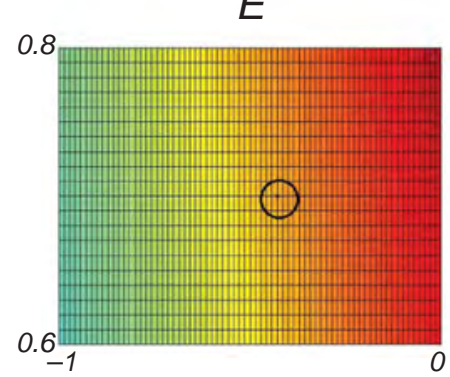

C

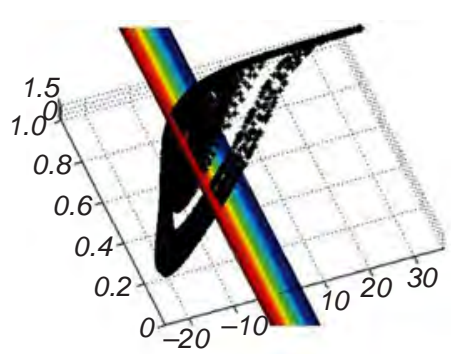

F

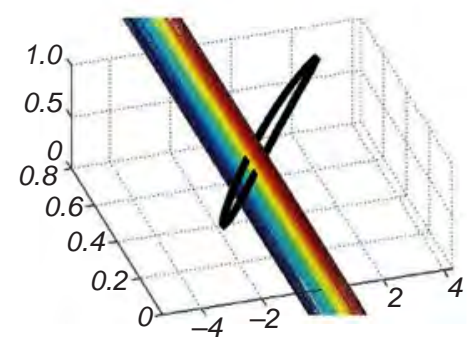

F i g. 7. Graphs of Poincare mapping. A, D) Firing patterns of the Purkinje cell at 36 and $63^{\circ} \mathrm{C}$, respectively; B, E) Poincare surfaces of section responds to two different systems; $\mathrm{C}, \mathrm{F}$ ) two different orbits in the given space. (axis $\mathrm{X}$ is the potential, axis $\mathrm{Y}$ is $\mathrm{mNaF}$, and axis $\mathrm{Z}$ is $\mathrm{mNaP}$ )

Р и с. 7. Результати побудови мап Пуанкаре.

examined.

By comparison of the effects of two different temperatures, it can be found that the current-voltage diagram shows certain specified changes in time. Estimation of different shapes of current-voltage diagrams (different electric resistances) provides a convenient method to study the periodicity in electrical activity of the cell under study.

Analysis of Poincare Mapping. The so-called Poincare map is the intersection of a periodic orbit in the given space of an uninterrupted dynamical system with a certain lower-dimensional subspace (called the Poincare surface of section), transversal to the flow of the system.

According to the point of intersection between the periodic orbit and Poincare surface of section, the periodic motion in the phase space can be discovered. If the point of intersection includes only one stationary point or a few discrete points, the motion is periodic. Conversely, if the point of intersection is dense and unordered, the motion is chaotic. In addition, if the point of intersection looks as a closed curve, the motion is quasiperiodic. In our study, we used Poincare mapping to explain some special cases of the firing periodicity. Here, we mainly analyzed the impact of temperature, while other parameters were left stable.

In Fig. 7B (the black area), there are several points of intersection on the Poincare surface in response to A. This corresponds to the functioning of the system with several period-doubling spiking. In contrast, there is only one stable point of intersection on the Poincare surface in $\mathrm{D}$ (responses to $\mathrm{C}$ ), which represents the system with one period-doubling spiking.

Poincare mapping is rather practical to resolve some problems related to the periodicity.

\section{DISCUSSION}

By studying the mechanisms of the formation of firing patterns in the somatic compartmental model, one can gain perceptions into a series of firing modes and some dynamic behaviors. Such interpretations can help researchers to understand what factors might impact the above firing patterns. Based on a single somatic compartmental model, we performed the dynamic analyzes of behavior of a cortical Purkinje cell that can generate complex spikes. This allowed us to gain several theoretical results summarized below:

External stimuli and changes in the $\mathrm{NaF}$ conductance, $\mathrm{CaT}$ conductance, and temperature would significantly influence the firing pattern in the soma. The respective changes include modifications of the distributions of interspike intervals (ISIs), 
Max-Min potential diagrams, frequency graphs, and current-voltage diagrams for different ions. Changes of the electrophysiological parameters listed above induce period-doubling and period-adding bifurcation phenomena. The frequency diagrams show that spiking of the cell examined increases firstly and then decreases. With increases of all kinds of the electrophysiological parameters, the current-voltage diagrams become limited into a regular area, and the electric resistance tends to manifest periodical oscillations.

Poincare mapping was applied to research the behavior of a chaotic system, a periodic system, and transformations between these two states. By comparison of two different firing patterns and points on the Poincare surface of section, it becomes obvious that these two systems can be rather easily differentiated, and some "periodic" problems can be resolved.

From the aforementioned analyses, it is essentially important to take into account that the repertoire of firing patterns of the Purkinje cell is really abundant, and some important information can be obtained according to the results of alteration of different factors in the model used. As is well known, a problem of neural coding is one of the scientific frontier and hot topics at present. So, the research of specificities of generation of AP sequences and varying modes among different firing patterns are becoming more and more necessary and expedient. However, since the whole neuron code researches are too complex in bio-experiments, the model computation results in mathematics will support the research a lot in the future.

Acknowledgments. The authors would like to acknowledge the generous support by the National Undergraduates Innovating Experimentation Project of China, No. 111056144.

Appendix A. Supporting information. Supplementary data associated with this article can be found in the online version at http://neuromorpho.org.

This study was not associated with any experiments on animals or tests involving human subjects; therefore, confirmation of compliance with existing ethical standards is not required from this aspect.

The authors of this study, X. Zhang, S. Q. Liu, H. X. Ren, Y. Wen, and Y. J. Zeng, confirm that the research and publication of the results were not associated with any conflicts regarding commercial or financial relations, relations with organizations and/or individuals who may have been related to the study, and interrelations betveen co-authors of the article.
Кс. Жанг'

\section{ДИНАМІЧНІ ВЛАСТИВОСТІ КЛІТИН ПУРКІН'Є, ЩО МАЮТЬ РІЗНІ ЕЛЕКТРОФІЗІОЛОГІЧНІ ПАРАМЕТРИ: МОДЕЛЬНЕ ДОСЛІДЖЕННЯ}

1 Південно-Китайський еехнологічній університет, Гуанжоу (Китай).

2 Пекінський технологічний університет, Центр біомедичного інженирінга, Пекін (Китай).

P е 3 ю м е

Генерація простих та складних потенціалів дії є специфічною властивістю нейронів мозочкової кори; моторне навчання i процеси формування пам'яті залежать від генерації даних патернів розряду. В нашій роботі ми провелидетальне дослідження процесів генерації імпульсної активності клітинами Пуркін'є з використанням компартментної (включаючи сому) моделі нейрона. В умовах прикладання оцифрованих стимулів у модельованого нейрона проявлвся багатий набір динамічних властивостей, що зумовлювало генерацію різноманітних розрядних патернів; це відбивалось у відповідних діаграмах максимальних/мінімальнихпотенціалів для кожного піку та появі біфуркацій із феноменами додання або подвоєння періодів. Були побудовані діаграми міжімпульсних інтервалів, значень частоти та залежностей струм-потенціал для різних іонів. Нарешті, побудова мап Пуанкаре була використана як теоретичний метод для переконливої диференціації часових характеристик зазначених вище розрядних патернів. Як показали результати нашого моделювання, розрядна активність клітин Пуркін'є динамічно змінюється залежно від варіації електрофізіологічних параметрів цих нейронів, і відповідні властивості можуть відігравати істотну роль у формації згаданих вище характеристик динамічних розрядів, що мають відношення до стратегії кодування в перебігу обробки інформації та процесів навчання.

\section{REFERENCE}

1. D. Purves, G. J. Augustine, D. Fitzpatrick, et al., Neuroscience (4th edition), Sinauer Ass., Sunderland (MA) (2008).

2. R. D Traub, S. J. Middleton, T. Knöpfel, and M. A. Whittington, "Model of very fast $(>75 \mathrm{~Hz})$ network oscillations generated by electrical coupling between the proximal axons of cerebellar Purkinje cells," Eur. J. Neurosci., 28, No. 8, 1603-1616 (2008).

3. J. I. Wadiche and C. E. Jahr, "Multivesicular release at climbing fiber-Purkinje cell synapses," Neuron, 32, No. 2, 301-313 (2001).

4. H. Anwar, S. Hong, and E. D. Schutter, "Controlling $\mathrm{Ca}^{2+}-$ activated $\mathrm{K}^{+}$channels with models of $\mathrm{Ca}^{2+}$ buffering in Purkinje cells," Cerebellum, 11, No. 3, 681-693 (2012).

5. M. A. Kramer, R. D. Traub, and N. J. Kopell, "New dynamics in cerebellar Purkinje cells: torus canards," Phys. Rev. Lett., 101, No. 6, 068103 (2008). 
6. A. M. Swensen and B. P. Bean, "Ionic mechanisms of burst firing in dissociated Purkinje neurons," J. Neurosci., 23, No. 29, 9650-9663 (2003).

7. I. M. Raman and B. P. Bean, "Ionic currents underlying spontaneous action potentials in isolated cerebellar Purkinje neurons," J. Neurosci., 19, No. 5, 1663-1674 (1999).

8. A. Roth and M. Häusser, "Compartmental models of rat cerebellar Purkinje cells based on simultaneous somatic and dendritic patch-clamp recordings," J. Physiol., 535, 445-472 (2001).

9. W. Akemann and T. Knopfel, "Interaction of Kv3 potassium channels and resurgent sodium current influences the rate of spontaneous firing of Purkinje neurons," J. Neurosci., 26, No. 17, 4602-4612 (2006).

10. W. M. Yamada, C. Koch, and P. R. Adams, Methods in Neuronal Modeling, Cambridge, MIT Press, London (1987).

11. A. L. Hodgkin, A. F. Huxley, "Currents carried by sodium and potassium ions through the membrane of the giant axon of Loligo," J. Physiol., 116, 449-472 (1952).

12. E. D. Schutter and J. M. Bower, "An active membrane model of the cerebellar Purkinje cell I. Simulation of current clamps in slice," J. Neurophysiol., 71, No. 1. 375-400 (1994).

13. T. Miyasho, H. Takagi, H. Suzuki, et al., "Low-threshold potassium channels and a low-threshold calcium channel regulate $\mathrm{Ca}^{2+}$ spike firing in the dendrites of cerebellar Purkinje neurons: A modeling study," Brain Res., 891, 106-115 (2001)

14. U. Wolf, M. J. Rapoport, and T. A. Schweizer, "Evaluating the affective component of the cerebellar cognitive affective syndrome," J. Neuropsychiat. Clin. Neurosci., 21, No. 3, $245-$ 53 (2009).

15. M. D. Womack, C. Chevez, and K. Khodakhah, "Calciumactivated potassium channels are selectively coupled to P/Qtype calcium channels in cerebellar Purkinje neurons," $J$. Neurosci., 24, No. 40, 8818-8822 (2004).

16. P. Wang, Q. H. Song, Q. M Zeng, et al., "The research about the inductance characteristics of potassium channel," Beijing Biomed. Eng., 22, No. 1, 77-79 (2003).

17. Y. Loewenstein, S. Mahon, P. Chadderton, et al., "Bistability of cerebellar Purkinje cells modulated by sensory stimulation," Nat. Neurosci., 8, 202-211 (2005). 